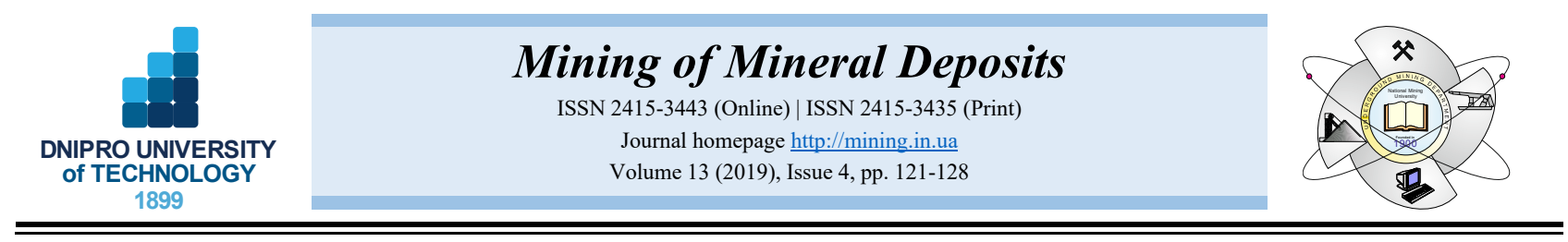

UDC 622.812 .2

https://doi.org/10.33271/mining13.04.121

\title{
FAULT TREE ANALYSIS AND PREVENTION STRATEGIES FOR GAS EXPLOSION IN UNDERGROUND COAL MINES OF PAKISTAN
}

\author{
N.M. Shahani ${ }^{1}$, M.J. Sajid ${ }^{2}$, X. Zheng ${ }^{1 *}$, I.M. Jiskani ${ }^{1}$, M.A. Brohi ${ }^{3}$, M. Ali ${ }^{1,3}$, B. Ullah ${ }^{1}$, A.R. Qureshi ${ }^{3}$ \\ ${ }^{1}$ China University of Mining and Technology, Xuzhou, China \\ ${ }^{2}$ Xuzhou University of Technology, Xuzhou, China \\ ${ }^{3}$ Balochistan University of Information Technology, Engineering and Management Sciences, Quetta, Pakistan \\ *Corresponding author: e-mail ckzxg@126.com,tel.+8613912041768
}

\begin{abstract}
Purpose. Gas explosion in the underground coal mines of Pakistan is the main source of coal miners' mortalities. The purpose of this article is to analyze the main causes of gas explosion in the underground coal mines of Pakistan.

Methods. The study employs the Fault Tree Analysis (FTA) to understand the key root causes that lead to system failure. Particularly, this research has articulated the fault tree model in case of gas explosion in underground coal mines to analyze the root causes of this dangerous accident.

Findings. This analysis has revealed that most of the root causes (4/7) with 5/10 accidents, 49/53 fatalities and 28/35 injuries resulted from primary failure of the gas explosion that poses a major threat to lives of mine workers. Similarly, the accumulation of gases and ignition are leading causes of gas explosion.

Originality. FTA has been employed for the first time to understand the underlying root causes with the corresponding number of accident, fatalities and injuries of gas explosion in underground coal mines of Pakistan. This original application of FTA to the problem under discussion presents some important underlying factors which should be considered to reduce the risk of gas explosion and its related fatal and non-fatal accidents.

Practical implications. The study proposes preventive strategies to lessen the fatal and non-fatal accidents resulting from gas explosions. Explicitly, Pakistan has to conduct major structural and safety management reforms.
\end{abstract}

Keywords: fault tree analysis, gas explosion, ignition, occupational health and safety, preventive strategies

\section{INTRODUCTION}

Coal mining is considered a dangerous occupation amongst all because of its risky and dangerous atmosphere (Donoghue, 2004; Sari, Selcuk, Karpuz, \& Duzgun, 2009; Shahani, Wan, Ali, \& Ullah, 2018). Accidents have the potential to prompt loss or injury and are causes of risk (Liu, Meng, Hassall, \& Li, 2016), confir-ming the coal mining sector's safety level of production is based upon "Coal-mine safety regulations" (Liu, Li, \& Meng, 2019). To cope with the problem, preventive coal mine strategies are essential to launch in order to minimize the ratio of accidents in Pakistani coal mines. Taking figures from the past data, gas explosions are ranked as the most serious cause of accidents in coal mines during production process in Pakistan (Shahani et al., 2019). Based on scientific investigation, these accidents accounted for $19 \%$ of all significant coal mine accidents and $17 \%$ of casualties as shown in Figure 1.
Coal deposits release significant amounts of methane $\left(\mathrm{CH}_{4}\right)$ gas that is flammable in nature when mixed with air in concentrations between 5 and 16\% (Brune, Cashdollar, \& Zipf, 2019). Methane and coal dust are considered as two important reasons for explosions. Normally, methane explosions occur when a buildup of methane gas contacts a heat source or if there is not enough air and ventilation to dilute the gas level below its explosion point. Similarly, fine particles of coal dust in right concentration that contact a source of heat could result in severe explosion (Niosh, 2012). Thus, coal mine operators need careful ventilation in underground mine openings to dilute and render harmless concentrations of methane to prevent ignitions and explosions. In this manner, gas explosion preventing strategies should be a key concern for improving coal mine safety and minimizing accidents. In this study, single time accidents, causalities and injuries that occurred in 9 years during $2010-2018$ were selected for the purpose of scientific analysis. 
(a)

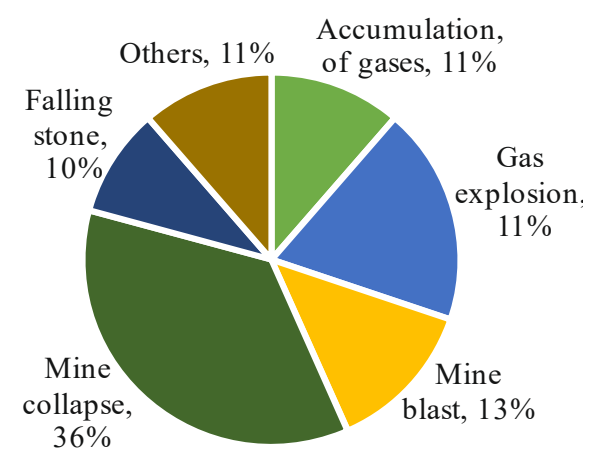

(b)

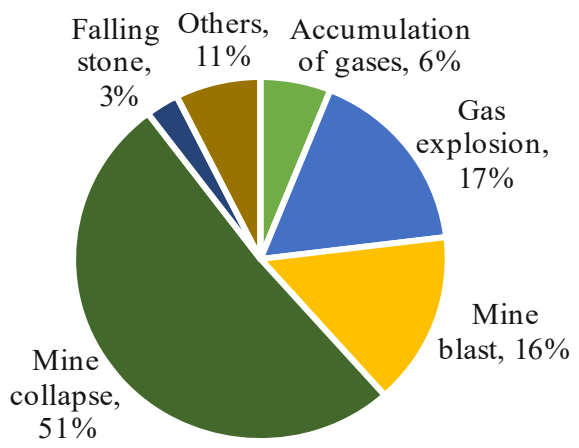

Figure 1. Classification of accidents and fatalities in (\%) from 2010 - 2018 of major coalfields in Pakistan (Shahani et al., 2019)

The proper and careful analysis of accidents could prevent or lessen the accidents in future and show the effect of empirical analysis dealing with accidents, fatalities and injuries that occurred in coal mines in Pakistan. The current research literature fails to identify root causes of accidents and offer prevention methods. Similarly, accident, fatality and injury analysis seems to be incomprehensible or unspecific; therefore, there is a need for strengthening preventive strategies to lessen the effect of fatal and non-fatal accidents (Xie et al., 2019). To address the problem, this paper analyses gas explosions by using FTA method to achieve a proper understanding of key root causes related to the corresponding number of accidents, fatalities and injuries, and to work out effective prevention strategies to reduce the number of gas explosion accidents in coal mines of Pakistan.

\section{HIGHLIGHTS OF COAL MINING WORKING CONDITIONS IN PAKISTAN}

Pakistan is the coal-rich industry and is placed top $7^{\text {th }}$ around the globe in terms of coal potential (Shahani et al., 2019a; Shahani et al., 2019b). Total reserves are appro-ximately 200 billion tons, however, due to the lack of financial resources and technical skills, no proper attention has been given to this particular sector since the past many years.

Presently, the major production of coal is mainly achieved by using traditional underground mining methods like longwall and room-and-pillar methods. Additionally, due to the shortage of technological incapability and financial constraints, there is no effective mechaniza- tion system within Pakistan, and therefore, coal is extracted manually by using human-work efforts with Pickaxes. Additionally, excluding few coal mines, animals like donkeys are being used for the source of transportation (haulage) of coal from underground to the surface.

Keeping in mind safety issues, as compared to other countries, Pakistan's mine management system fails to comply with international safety standards; thus, the fatal and non-fatal accidents are getting more numerous. Frequent accidents in underground coal mines result from accumulation of gases, gas explosion, mine blast, mine collapse, falling stone, and so on. Consequently, the maximum number of fatal and non-fatal accidents are caused by a gas explosion after mine collapse, which is the main objective of this paper. Moreover, such circumstances increase the scary conditions miners have to work in. Therefore, Pakistan has to take major structural and safety management reforms like "the application of engineering design, adoption of effective technology, administration of safety laws, and additional efforts to workforce education related to safety as a prerequisite" (Jiskani et al., 2019). Figure 2 shows the location of the significant coalfields in Pakistan.

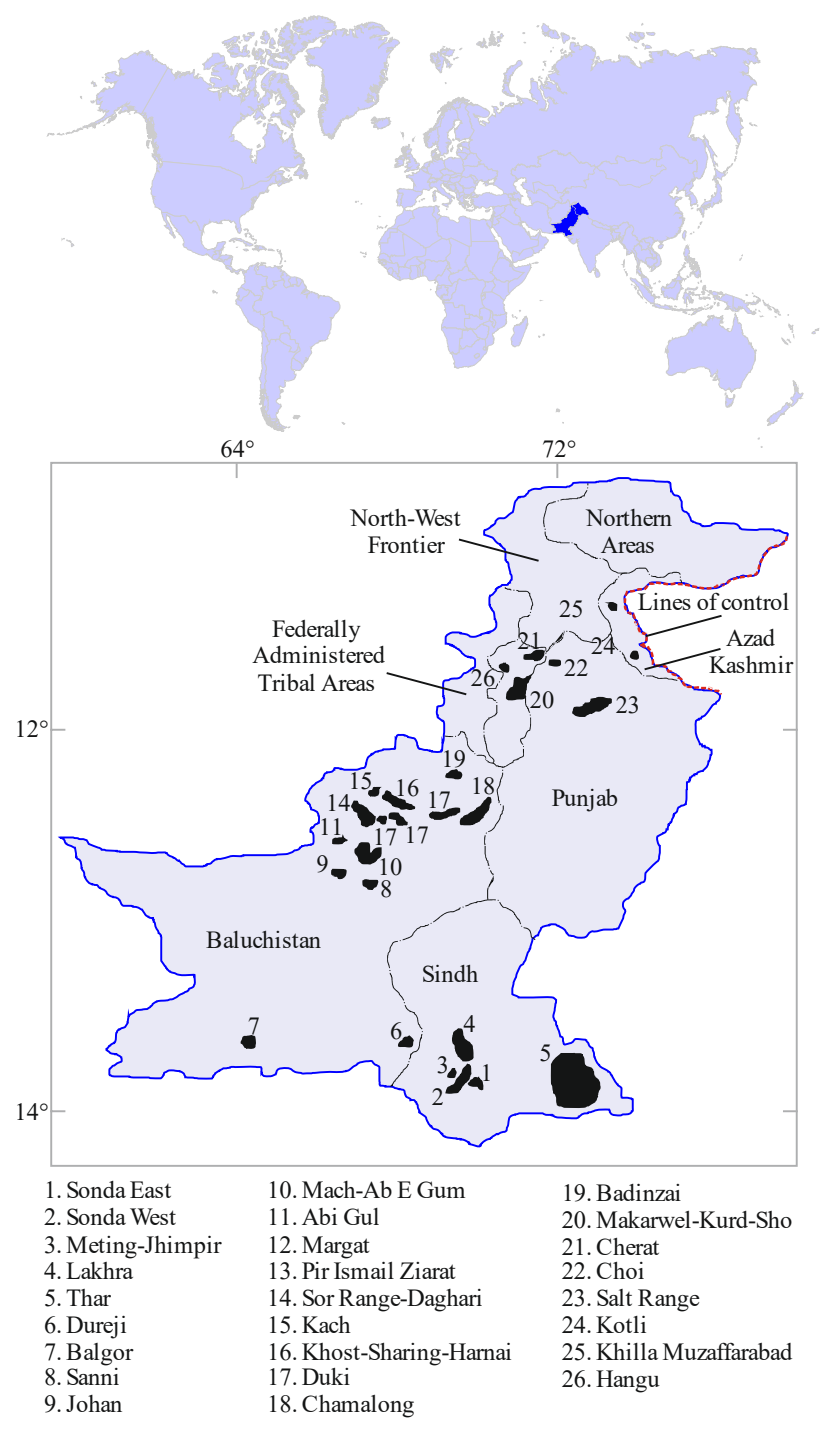

Figure 2. Spatial location of Pakistan and its major coalfields (a modified version of Sohail, Huang, Bailey, Akhtar, \& Talib, 2013) 
Figure 3 denotes the highlights of coal mine working conditions in Pakistan.
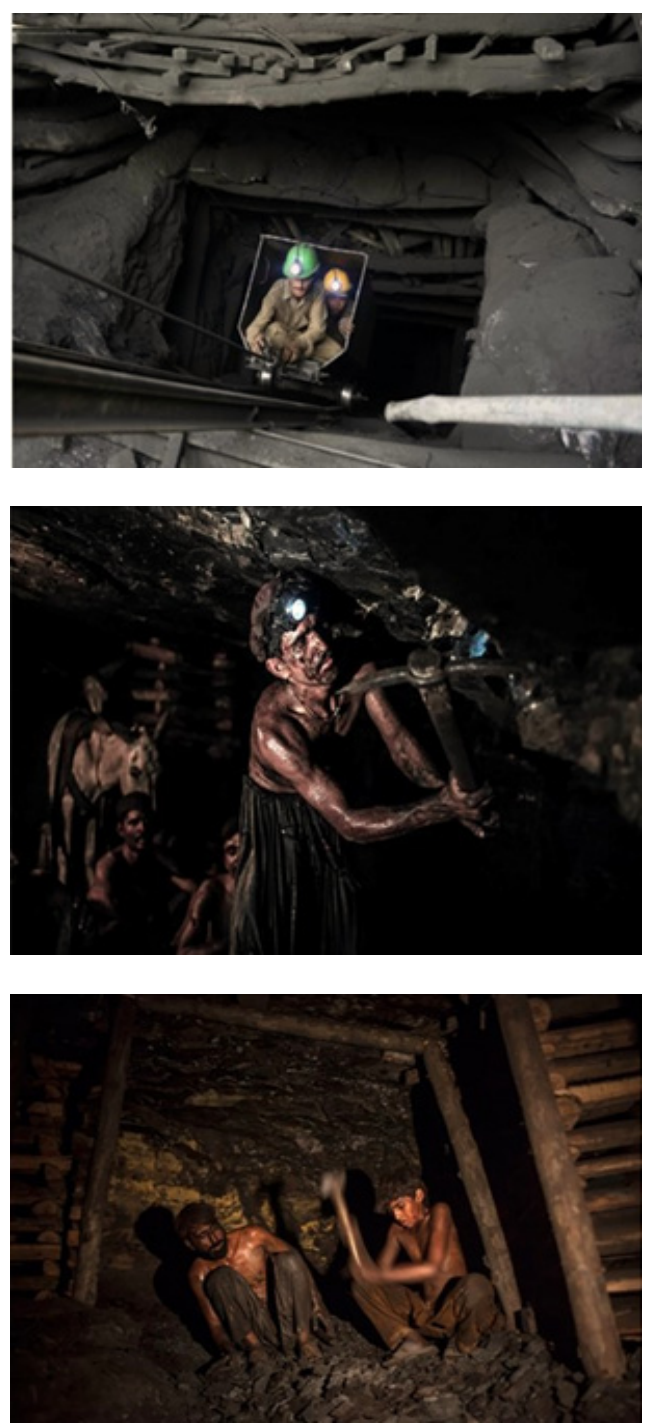

Figure 3. Highlights of coal mine working conditions in Pakistan (Sim, 2014; IndustriALL, 2015)

\section{FAULT TREE ANALYSIS (FTA)}

Fault Tree Analysis (FTA) is regarded as one of crucial symbolic, logic, and analytical techniques among various scientific techniques. It was first used in aerospace industry, but its usage has been transferred on to different other industries, like nuclear industry, offshore chemical (Yuhua \& Datao, 2005), and mining (Zhang, Kecojevic, \& Komljenovic, 2014) industries since 1979 (Lavasani, Wang, Yang, \& Finlay, 2011).

It is a system analysis technique for determining the root causes and the probability of a specified undesired event occurrence. Many authors or organizations have described the method in literature (NASA, 2002; Ericson, 2005; IEC, 2006; Oakley, 2012; Harms-Ringdahl, 2013). Figure 4 shows the initial 5 stages comprising the FTA's problem development. The other 3 stages cover the FT construction, its assessment, and lastly the explanation of FT outcomes. Though almost all stages are accomplished successively, stages 3 to 5 could be carried on simultaneously.

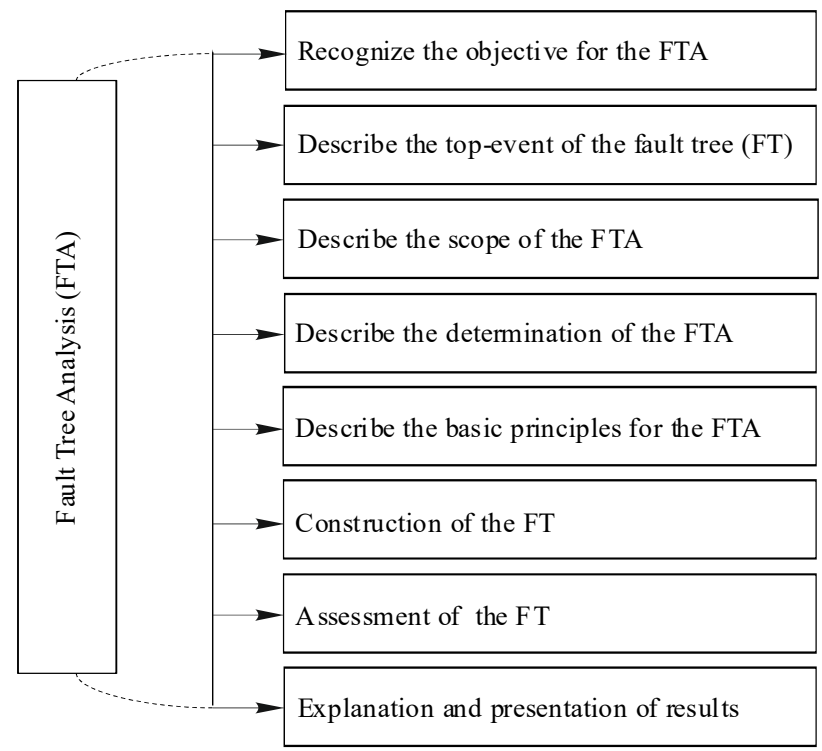

Figure 4. General procedure for the fault tree analysis (NASA, 2002)

Stage 4 and stage 5 could be changed in the course by stage 6 and stage 7 . There are 3 key models proposed (Ericson, 2005), but this study practices the State-ofComponent $(S C)$ model, which continues seeking the primary $(P)$, secondary $(S)$ and command $(C)$ failure root causes of the incident respectively.

For example, "an electric motor fails to work" is a primary failure, and the primary failure is considered as an integral part of the system component. An electric motor fails to work because of other sources (i.e. no power to an electric motor) which means it is a secondary failure. "A command failure" is a predictable, or anticipated incident that follows during an undesirable period because of identified failure." (Ericson, 2005). "A command failure is such a failure in the missile arm and fire functions which launches the missile before the usual time".

\section{METHODS}

The methodological approach towards achieving the objectives of this study is an empirical analysis of the underground coal mines gas explosion based on data from 2010 to 2018 . The multiple data collection methods were used (IndustriALL, 2016; IndustriALL, 2017; IndustriALL, 2018) to identify the exact number of accidents with related fatalities and injuries caused by these accidents. Next, the FTA analysis of gas explosion in underground coal mines is studied both qualitatively and quantitatively for better understanding of the primary root causes of accidents. Finally, some prevention strategies are also put forward to address the subject matter.

\section{RESULT ANALYSIS}

Based on the collected data from 2010 to 2018, the underground coal mine gas explosion accidents, fatalities and injuries were statistically analysed and studied. As shown in Figure 5, a total number of 11 accidents caused 53 deaths and 35 injuries from 2010 to 2018 in Pakistan. An average of $\sim 1$ gas explosion accident happened every year. 


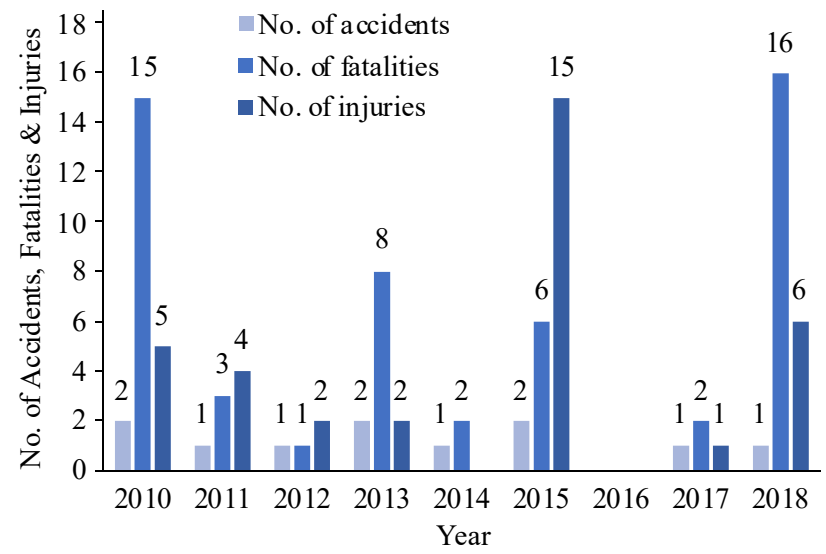

Figure 5. Underground coal mine gas explosion accidents, fatalities and injuries from $2010-2018$

Similarly, the average of $\sim 5$ deaths and $\sim 3$ injuries counted by each accident per year. This clearly shows that the number of fatalities and injuries is increasing with the increasing number of accidents. Figure 6 denotes the causes for accidents, fatalities and injuries. Thus, the major causes of fatal and non-fatal accidents in coal mines of Pakistan are: accumulation of gas $(5 / 10$ accidents, $49 / 53$ fatalities and 28/35 injuries) and ignition sources (5/10 accidents, $4 / 53$ fatalities and 7/35 injuries).

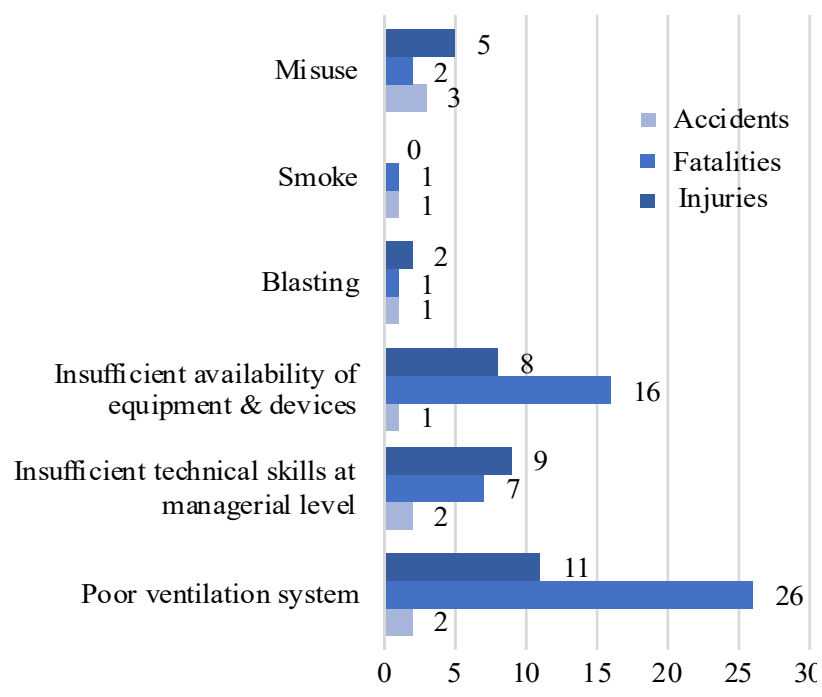

Figure 6. Cause-wise number of accidents, fatalities and injuries

\subsection{Fault tree}

This study focuses on primary and some common causes of gas explosions in underground coal mines in Pakistan. As Fault tree analysis gives an exact picture of the total number of accidents which happened during the said period, it was essential to go through FTA analysis for better understanding the nature of the problem. This study uses the FTA method to analyze the causes of gas explosion in coal mining and measures for its prevention. The diagram of gas explosion fault tree was constructed based on the primary $(P)$, secondary $(S)$, and command (C) causes of the event as shown in Figure 7. The root causes (i.e. the basic events in the FT) were constructed based on the current working conditions and methodology in coal mines of Pakistan. Table 1 shows elimination of gas explosion root causes.
Table 2 shows the primary, secondary and command root causes along with a relative number of accidents, fatalities and injuries that must be eliminated or should be adequately controlled to ensure the safe working conditions for coal miners. Consequently, the highest number of root causes (4/7) was contributed by the primary root cause and it resulted in 5/10 accidents, 49/53 fatalities and 28/35 injuries. Similarly, the total number of secondary and command root causes are $2 / 7$ and $1 / 7$ with $3 / 10$ accidents, $2 / 53$ fatalities and $2 / 35$ injuries; $2 / 10$ accidents, $2 / 53$ fatalities and 5/35 injuries respectively. All these root causes could be mitigated by adequate design of mines, regular mines inspection, compliance with the suggested mine safety rules and regulations, etc. In detail, related safety measures are discussed in the conclusion and preventive strategies section.

\section{CONCLUSION AND PREVENTION STRATEGIES}

Mining work remains dangerous in many countries despite improvements in occupational health and safety during current years. Safety development policies and strategies must be a part of global risk mitigation. Otherwise, it will add to the loss of lives of many workers throughout the world. FTA is one of the approaches used to correctly diagnose the root causes of accidents and therefore, to avoid the incidence of such accidents in the future. Gas explosion accidents are ranked as the biggest disasters after mine collapse accidents in coal mines of Pakistan.

Findings of this research indicate that major root causes are related to gas explosion. Moreover, to prevent such gas explosion (methane gas and coal dust explosions) accidents, various approaches could be employed. "The basic remedial strategies are to prevent the existence and accumulation of combustible bodies of methane and to eradicate sources of ignition like exposed fires, frictional and electrical flashes, heat from spontaneously combusting coal and heat from mining equipment comprising, nonetheless not restricted to hot exhaust manifolds and frictional heat (belts, brakes)". Based on this study, the following sections confer these options in detail to address the gas explosion accidents for the wellbeing of coal mine workers not only in Pakistan but also in coal mines of other countries.

\subsection{Adequate supply of ventilation}

Preventing the buildup of combustible gases is generally accomplished through proper techniques like sufficient amount of ventilation in all mine passways and the discharge of methane $\left(\mathrm{CH}_{4}\right)$ from the coalbed earlier to and during the mining operation. The system of the mine ventilation should be carefully designed so that all mine passways must be adequately ventilated with sufficient quantities of air to reduce accumulations of $\mathrm{CH}_{4}$ in intake air paths to less than or equal to $1 \%$ (Unites States Code of Federal Regulations, 2019). If higher concentrations of $\mathrm{CH}_{4}$ are identified in intake air paths, all the motor-powered equipment must be powered off, and the control of ventilation should also be adjusted so that concentration of $\mathrm{CH}_{4}$ lessens to $1 \%$ (Kissell, 2006). 


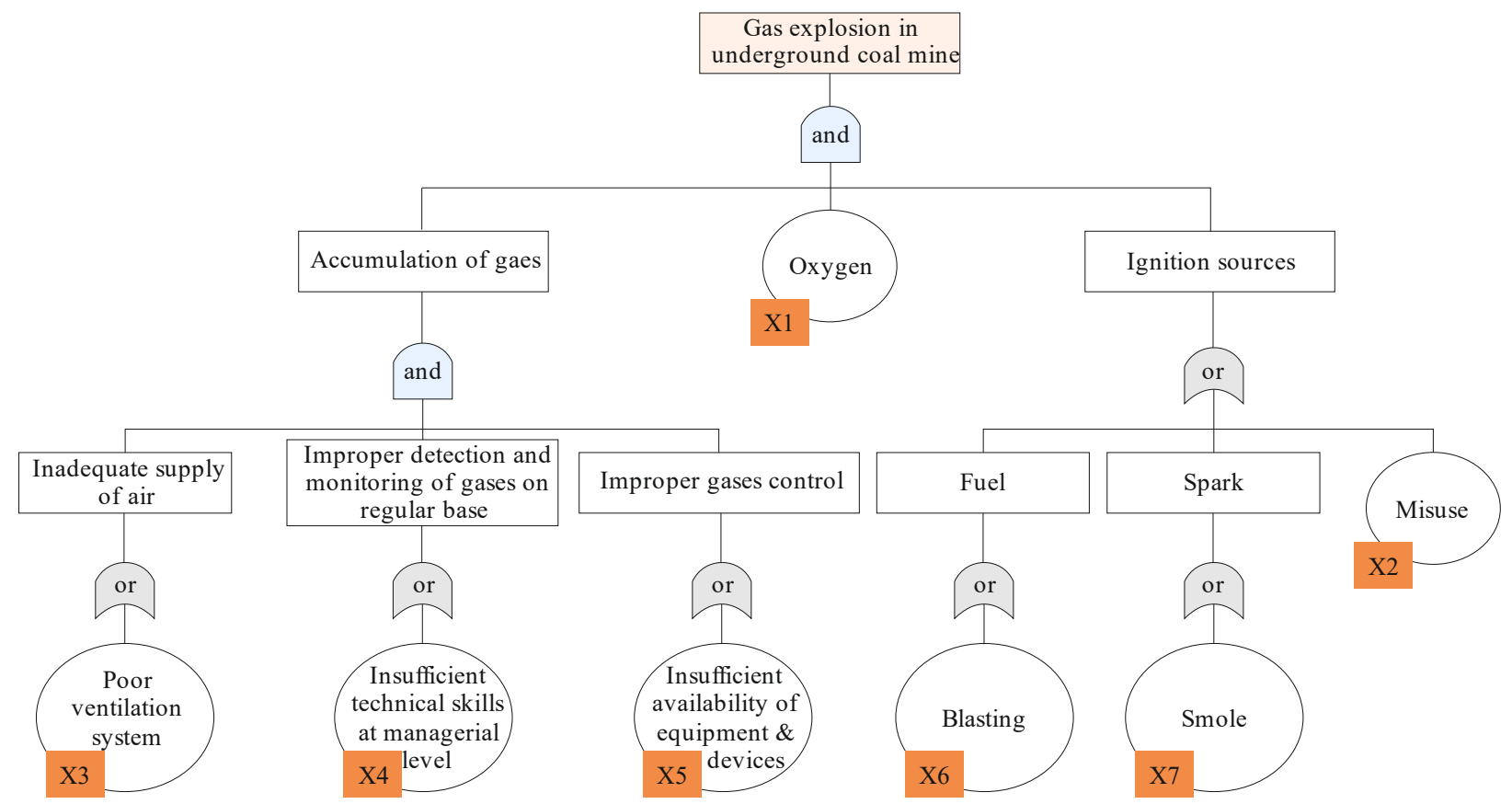

Table 1. Gas explosion root causes that could be eliminated

\begin{tabular}{|c|c|c|c|c|c|}
\hline Root causes & $\begin{array}{c}\text { Primary } \\
\text { failure }(P)\end{array}$ & $\begin{array}{l}\text { Secondary } \\
\text { failure }(S)\end{array}$ & $\begin{array}{l}\text { Command } \\
\text { fault }(C)\end{array}$ & Solution & Solution sorts \\
\hline $\mathrm{X} 1 \& \mathrm{X} 3$ & $\sqrt{ }$ & & & Design & $\begin{array}{c}\text { Installation of extra fans for an adequate } \\
\text { supply of ventilation }\end{array}$ \\
\hline X4 & $\sqrt{ }$ & & & Best practices & $\begin{array}{l}\text { Improvement in technological skills and } \\
\text { awareness regarding safety }\end{array}$ \\
\hline $\mathrm{X} 5$ & $\sqrt{ }$ & & & Design & $\begin{array}{c}\text { Availability of latest safety devices and } \\
\text { equipment }\end{array}$ \\
\hline X2 & & & $\sqrt{ }$ & Best practices & $\begin{array}{l}\text { Visual examinations, maintenance, and } \\
\text { operating measures }\end{array}$ \\
\hline$X 6 \& X 7$ & & $\sqrt{ }$ & & Proper control & Suppress the sources of ignition \\
\hline
\end{tabular}

Table 2. Gas explosion root causes that could be eliminated

\begin{tabular}{ccccc}
\hline Item & Primary & Secondary & Command & Total \\
\hline Root causes & 4 & 2 & 1 & 7 \\
Accidents & 5 & 3 & 2 & 10 \\
Fatalities & 49 & 2 & 2 & 53 \\
Injuries & 28 & 2 & 5 & 35 \\
\hline
\end{tabular}

A substantial level of safety under the "lower flammable limit 5\%" should be ensured to safeguard coal mine workers from $\mathrm{CH}_{4}$ explosions.

All operational places of the mine (the areas where miners work) must be checked regularly for the appropriate ventilation within a few hours before work. In addition to that, all other working zones should be examined minimum once or twice a week for the amount of ventilation and any accumulations of $\mathrm{CH}_{4}$ at particular investigation marks.

Mined out areas or goaf area of the mine must be closed by the explosion-proof barricades from all accesses guiding to this zone. After this area is closed, it will be no longer ventilated and $\mathrm{CH}_{4}$ could be indorsed to store inside the restricted zone.

At present, new principles are successfully implemented (Zipf, Sapko, \& Brune, 2007). They demand building the explosion-proof barricades with a minimum pressure of 50 psi and efficient examination of the environment beyond such barricades.

\subsection{Proper drainage of methane gas}

By supplying fresh air to ventilate the mine entrances, $\mathrm{CH}_{4}$ concentration is reduced, which ensures its drainage from working coalbed and adjacent coalbeds above or below active seams. Additionally, methane discharge should be carried out before mining through drilling boreholes into the coal from nearby mine passways. Draining $\mathrm{CH}_{4}$ from mined out areas that are greatly cracked after the coal has been mined (particularly by a longwall method) can be an effective technique to avoid $\mathrm{CH}_{4}$ release from coalbeds situated above the coal extracted in operational areas.

\subsection{Prevention of ignitable matter accumulation}

To prevent the development of ignitable coal haze, rock or pulverized particles of limestone, it is recommended to spray above the "coal dust" generated in the course of mining in mine accesses to develop an inert dust combination. To reduce the concentration of such coal dust and make it adequately inert, as stated by the 
proposed rules, fine limestone particles should be mixed with coal dust in such a way that there should be at least $65 \%$ of noninflammable substance in all intake entrances and $80 \%$ of noninflammable substances in return air routes (Nagy, 1981). The noninflammable substance contains coal moisture and ash, additional fine particles of rock, and any other inert mine dust (like shale in the roof or floor rock of mine). The added limestone dust is essential to permit about $70 \%$ through a 200 -mesh or $75 \mu \mathrm{m}$ screen. A greater noninflammable content is essential in return air passages since the dust of coal transported through the supply of ventilation is supposed to be pulverized in size. "This "float coal dust" is defined as dust that permits a 200 -mesh $(75 \mu \mathrm{m})$ sieve".

Water sprays are the best option to reduce the production of "float coal dust" and transfer it into the ventilation during mining and carrying of coal. All operational equipment in mine is usually armed with water sprays. However, this equipment typically is placed next to cutting drums, crushers and conveyor transfer points.

The limestone rock dust behaves as a "heat sink" (heat sink is a device or material absorbing the extreme quantity of heat), and the prevention of coal-dust explosion is only achieved through the sufficient quantity of rock dust added to the coal-dust (Nagy, 1981). It should be spread in the all mining passages by air-filled spray rags along with trickle rags, which are practiced in the return entrances of longwall and continuous miner units.

It is essential that mine inspectors and operators should inspect and notice the quality of "inertization" in the course of all ventilation investigations on the constant basis to make sure that proper quantities of rock dust are available. The presently established "Coal Dust Explosibility Meter" (Sapko \& Verakis, 2006) allows prompt calculation of the acceptability of rock dust application by an optical reflectivity analysis. Finally, the misuse of the ignitable matter is also a big problem, so it is recommended to avoid such mishandling of all combustible matters during mining operations.

\subsection{Suppression of the potential sources of ignition}

One more practice for protection against gas explosions is to suppress all potential ignition sources. All machinery or equipment, which is used for underground coal extraction must be acceptable by safety-related standards for safe coal production. Usually, the approved powered equipment is supplied by explosion-resistant enclosures, which averts the $\mathrm{CH}_{4}$ ignition sources inside the powered motors from igniting a combustible $\mathrm{CH}_{4}$ surrounding exterior. Additionally, the equipment (like continuous miners and longwall shearers) used in coal mines for the extraction of coal is supplied with $\mathrm{CH}_{4}$ monitors, which are regulated to alarm the person responsible for the equipment if the concentrations of $\mathrm{CH}_{4}$ rise over $1 \%$. When the concentration of $\mathrm{CH}_{4}$ exceeds $1.5 \%$, all the electrical equipment must be powered off at all electrical sources.

The diesel engines powered equipment must be approved through suggested mining codes concerning "the surface temperature, exhaust gas temperature and exhaust gas quality" to be considered permitted in coal mines (Nagy, 1981).

The flames and smoking should be strictly prevented in underground coal mines. Though, whenever it be- comes compulsory to work under flame during welding and cutting actions, special safety measures should be carried to avoid $\mathrm{CH}_{4}$ explosions. These safety measures suppose observing the working atmosphere through recognized mine investigator at the welding areas for the occurrence of $\mathrm{CH}_{4}$.

The permissible explosives should be practiced for mining operation whenever necessary, which must be approved by associated mining safety supervisory. Therefore, the permissible explosives are usually used without the risk of exploding a combustible $\mathrm{CH}_{4}$ environment.

\subsection{Prevention of gas explosions through equipment and safety supervision}

Working conditions at the majority of Pakistan's coal mines are very poor, the level of overall production technology is low, adding to this - poor equipment, outdated mining approaches, and the dearth of sufficient safety security in coal mines. The associated authorities should contribute to the positively safe working environment to ensure the safety of coal mine workers. Simultaneously, the safety mechanism within organizations should be evaluated on a regular basis, and the prevention mechanism of coal mine gas explosions through latest technological equipment should be ensured. The organization should invest more into security and safety of mine workers and meet the law standards specified by the state.

\subsection{Prevention of gas explosions through latest technological research}

Education linked to the mechanism of gas explosion should be further reinforced, the research on gas explosions enhancing expertise must be strengthened, the disaster alert should be referred to the related units and hazardous circumstances. Miners should be informed in accordance with the rules prior to the occurrence of gas explosion accident. Simultaneously, the obstacle to new technological research into gas explosions related accidents should be reinforced to decline the level of disasters in the coal mines of Pakistan.

\section{ACKNOWLEDGEMENTS}

This research was funded by the National Natural Science Foundation of China (51574226) and 2017 Special Project of Subject Frontiers Scientific Research in China University of Mining and Technology (2017XKQY047). Additionally, authors are very thankful to the School of Mines, China University of Mining and Technology, Xuzhou, 221116 China, whose support allowed to accomplish this research within the specified time.

\section{REFERENCES}

Brune, J.F., Cashdollar, K.L., \& Zipf, R.K. (2019). Explosion prevention in United States coal mines. Retrieved from https://www.cdc.gov/niosh/mining/works/coversheet891.html

Donoghue, A.M. (2004). Occupational health hazards in mining: An overview. Occupational Medicine, 54(5), 283-289. https://doi.org/10.1093/occmed/kqh072

Ericson II, C.A. (2005). Hazard analysis techniques for system safety. Hoboken, United States: John Wiley \& Sons.

Harms-Ringdahl, L. (2013). Guide to safety analysis for accident prevention. Stockholm, Sweden: IRS Riskhantering. 
IEC 61025. (2006). Fault tree analysis (FTA). International Electrotechnical Commission.

IndustriALL. (2015). Another coal mine explosion in Pakistan: Five killed and eight injured. Retrieved from http://www. industriall-union.org/another-coal-mine-explosion-in-pakistanfive-killed-and-eight-injured/

IndustriALL. (2016). Global Union. Retrieved from http://www.industriall-union.org/sites/default/files/uploads/ documents/2016/Pakistan/mining_accidents in pakistan_20102016.pdf.

IndustriALL. (2017). Global Union. Retrieved from http://www.industriall-union.org/four-coal-miners-die-inpakistan

IndustriALL. (2018). Global Union. Retrieved from http://www.industriall-union.org/pakistan-anger-soars-overfrequent-fatalities

Jiskani, I.M., Ullah, B., Shah, K.S., Bacha, S., Shahani, N.M., Ali, M., \& Qureshi, A.R. (2019). Overcoming mine safety crisis in Pakistan: An appraisal. Process Safety Progress, 38(4), 1-8. https://doi.org/10.1002/prs.12041

Kissell, F.N. (2006). Handbook for methane control in mining. Washington, United States: US Department of Health and Human Services. https://doi.org/10.26616/nioshpub2006127

Lavasani, M., Wang, J., Yang, Z., \& Finlay, J. (2011). Application of fuzzy fault tree analysis on oil and gas offshore pipelines. International Journal of Marine Science and Engineering, 1(1), 29-42.

Liu, Q., Li, X., \& Meng, X. (2019). Effectiveness research on the multi-player evolutionary game of coal-mine safety regulation in China based on system dynamics. Safety Science, (111), 224-233. https://doi.org/10.1016/j.ssci.2018.07.014

Liu, Q., Meng, X., Hassall, M., \& Li, X. (2016). Accidentcausing mechanism in coal mines based on hazards and polarized management. Safety Science, (85), 276-281. https://doi.org/10.1016/j.ssci.2016.01.012

Nagy, J. (1981). The explosion hazard in mining. Washington, United States: US Department of Labor.

National Aeronautics and Space Administration (NASA). (2002). Fault tree handbook with aerospace applications. office of safety and mission assurance. Washington, United States: NASA.

Niosh, M. (2012). Mining feature: coal mine explosion prevention. Retrieved from https://www.cdc.gov/niosh/mining/ features/coalmineexplosion.html

Oakley, J.S. (2012). Accident investigation techniques: Basic theories, analytical methods, applications. Washington, United States: American Society of Safety Engineers.

Sapko, M.J., \& Verakis, H. (2006). Technical development of the coal dust explosibility meter. SME Annual Meeting and
Exhibit. Littleton, United States: Society for Mining, Metallurgy, and Exploration.

Sari, M., Selcuk, A.S., Karpuz, C., \& Duzgun, H.S.B. (2009). Stochastic modeling of accident risks associated with an underground coal mine in Turkey. Safety Science, 47(1), 78-87. https://doi.org/10.1016/j.ssci.2007.12.004

Shahani, N.M., Wan, Z., Ali, M., \& Ullah, B. (2018). Detection and monitoring of underground coal mine gases at Lakhra Coal Mines, Pakistan. $35^{\text {th }}$ Annual International Pittsburgh Conference, 1-8.

Shahani, N.M., Sajid, M.J., Brohi, M.A., Qureshi, A.R., Shahani, L.B., Bacha, S., \& Ullah, B. (2019a). An empirical analysis of fatal accidents in the coal mines of Pakistan. Proceedings of the International Conference on Energy, Resources, Environment and Sustainable Development, 726-733.

Shahani, N.M., Wan, Z., Guichen, L., Siddiqui, F.I., Pathan, A.G., Yang, P., \& Liu, S. (2019b). Numerical analysis of top coal recovery ratio by using discrete element method. Pakistan Journal of Engineering and Applied Sciences, (25), 26-35.

Sim, D. (2014). Children and donkeys labouring underground in coal mine in Punjab Province, Pakistan. Retrieved from https://www.ibtimes.co.uk/children-donkeys-labouring-underground-coal-mine-punjab-province-pakistan-1459037/

Sohail, M.T., Huang, D., Bailey, E., Akhtar, M.M., \& Talib, M.A. (2013). Regulatory framework of mineral resources sector in Pakistan and investment proposal to Chinese companies in Pakistan. American Journal of Industrial and Business Management, 03(05), 514-524.

https://doi.org/10.4236/ajibm.2013.35059

Unites States Code of Federal Regulations. (2019). Title 30, Part 75.

Xie, X., Fu, G., Xue, Y., Zhao, Z., Chen, P., Lu, B., \& Jiang, S. (2019). Risk prediction and factors risk analysis based on IFOA-GRNN and apriori algorithms: Application of artificial intelligence in accident prevention. Process Safety and Environmental Protection, (122), 169-184. https://doi.org/10.1016/j.psep.2018.11.019

Yuhua, D., \& Datao, Y. (2005). Estimation of failure probability of oil and gas transmission pipelines by fuzzy fault tree analysis. Journal of Loss Prevention in the Process Industries, 18(2), 83-88. https://doi.org/10.1016/j.jlp.2004.12.003

Zhang, M., Kecojevic, V., \& Komljenovic, D. (2014). Investigation of haul truck-related fatal accidents in surface mining using fault tree analysis. Safety Science, (65), 106-117. https://doi.org/10.1016/j.ssci.2014.01.005

Zipf, R.K., Sapko, M., \& Brune, J.F. (2007). Explosion pressure design criteria for new seals in U.S. coal mines. Washington, United States: US Department of Health and Human Services. https://doi.org/10.26616/nioshpub2007144

\section{АНАЛІЗ ДЕРЕВА ВІДМОВ І СТРАТЕГІЇ ЗАПОБІГАННЯ ВИБУХІВ ГАЗУ В ПІДЗЕМНИХ ВУГІЛЬНИХ ШАХТАХ ПАКИСТАНУ}

\section{Н.М. Шахані, М.Дж. Саджід, Х. Чженг, І.М. Джіскані, М.А. Брохі, М. Алі, Б. Уллах, А.Р. Куреші}

Мета. Аналіз впливу основних факторів, що викликають вибухи шахтного газу метану, на основі складання моделі дерева відмов в умовах вугільних шахт Пакистану.

Методика. Для досягнення мети дослідження застосовано емпіричний аналіз вибухів газу у вугільних шахтах Пакистану на основі даних з 2010 по 2018 роки для визначення точного числа аварій зі смертельними випадками і травмами. Аналіз вибухів газу вивчався як якісно, так і кількісно для кращого розуміння першопричин, що створюють небезпечні аварійні ситуації на підставі аналізу дерева відмов (АДВ).

Результати. Встановлено, що 11 нещасних випадків привели до 53 смертельних випадків і 35 травм у період з 2010 по 2018 роки у Пакистані. Значна частина причин (4 з 7), що призвели до 5 з 10 нещасних випадків, 49 з 53 смертей та 28 з 35 травм, була пов'язана з вибухом газу, а основні фактори, що викликають вибух - це накопичення газу і його загоряння. Акцентовано увагу на належну якість проектування шахт, регулярний огляд шахт, дотримання пропонованих правил і норм безпеки. 
Наукова новизна. Метод АДВ було вперше застосовано для розуміння глибинних причин, що викликають вибух газу у вугільних шахтах Пакистану, а його специфікація дозволила виявити ряд важливих ключових факторів, які слід враховувати для зменшення ризику вибуху газу й запобігання викликаних ним аварій.

Практична значимість. Розроблено стратегічні заходи, що дозволяють запобігти або зменшити число аварій зі смертельними наслідками (або без них), викликаних вибухом газу. Для цієї мети пропонується, аби в Пакистані були проведені серйозні структурні реформи і перетворення в галузі охорони праці.

Ключові слова: аналіз дерева відмов, вибух газу, займання, професійне здоров'я $і$ охорона праці, стратегї запобігання аварій

\section{АНАЛИЗ ДЕРЕВА ОТКАЗОВ И СТРАТЕГИИ ПРЕДОТВРАЩЕНИЯ ВЗРЫВОВ ГАЗА В ПОДЗЕМНЫХ УГОЛЬНЫХ ШАХТАХ ПАКИСТАНА}

Н.М. Шахани, М.Дж. Саджид, Х. Чженг, И.М. Джискани, М.А. Брохи, М. Али, Б. Уллах, А.Р. Куреши

Цель. Анализ влияния основных факторов, вызывающих взрывы шахтного газа метана на основе составления модели дерева отказов в условиях угольных шахт Пакистана.

Методика. Для достижения цели исследования применен эмпирический анализ взрывов газа в угольных шахтах Пакистана на основе данных с 2010 по 2018 годы для определения точного числа аварий со смертельными случаями и травмами. Анализ взрывов газа изучался как качественно, так и количественно для лучшего понимания первопричин, которые создают опасные аварийные ситуации на основании анализа дерева отказов (АДО).

Результаты. Установлено, что 11 несчастных случаев привели к 53 смертельным случаям и 35 травмам в период с 2010 по 2018 годы в Пакистане. Значительная часть причин (4 из 7), приведших к 5 из 10 несчастных случаев, 49 из 53 смертей и 28 из 35 травм, была связана со взрывом газа, а основные факторы, вызывающие взрыв - это накопление газа и его возгорание. Акцентировано внимание на надлежащее качество проектирования шахт, регулярный осмотр шахт, соблюдение предлагаемых правил и норм безопасности шахт.

Научная новизна. Метод АДО был впервые применен впервые для понимания глубинных причин, вызывающих взрыв газа в угольных шахтах Пакистана, а его спецификация позволила выявить ряд важных ключевых факторов, которые следует учитывать для сокращения риска взрыва газа и предотвращения вызванных им аварий.

Практическая значимость. Разработаны стратегические меры, позволяющие предотвратить или уменьшить число аварий со смертельными последствиями (или без них), вызванных взрывом газа. Для этой цели предлагается, чтобы в Пакистане были проведены серьезные структурные реформы и преобразования в области охраны труда.

Ключевые слова: анализ дерева отказов, взрыв газа, воспламенение, профессиональное здоровье и охрана труда, стратегии предотвращения аварий

\section{ARTICLE INFO}

Received: 13 September 2019

Accepted: 19 November 2019

Available online: 4 December 2019

\section{ABOUT AUTHORS}

Niaz Muhammad Shahani, Candidate of Doctor of Philosophy, Research Scholar of the School of Mines, China University of Mining and Technology, Nanhu Campus, No. 1, Daxue Road, 221116, Xuzhou, China. E-mail: shahani.niaz@gmail.com

Muhammad Jawad Sajid, Doctor of Philosophy, Associate Professor of the School of Management, Xuzhou University of Technology, $3^{\text {rd }}$ Ring Rd S, 221000, Xuzhou, China. E-mail: jawad.jaws@outlook.com

Xigui Zheng, Doctor of Philosophy, Professor of the School of Mines, China University of Mining and Technology, Nanhu Campus, No. 1, Daxue Road, 221116, Xuzhou, China. E-mail: ckzxg@126.com

Izhar Mithal Jiskani, Candidate of Doctor of Philosophy, Research Scholar of the School of Mines, China University of Mining and Technology, Nanhu Campus, No. 1, Daxue Road, 221116, Xuzhou, China. E-mail: imjiskani@hotmail.com

Manzoor Ali Brohi, Doctor of Philosophy, Assistant Professor of the Department of Management, Balochistan University of Information Technology, Engineering and Management Sciences, Takatu campus, Airport Road, 87300, Quetta, Pakistan. E-mail: manzoor.ali@,buitms.edu.pk

Muhammad Ali, Candidate of Doctor of Safety Engineering, Assistant Professor of the Department of Mining Engineering, Balochistan University of Information Technology, Engineering and Management Sciences, Takatu Campus, Airport Road, 87300, Quetta, Pakistan. E-mail: ali.uet@icloud.com

Barkat Ullah, Candidate of Master of Engineering, School of Safery Engineering, China University of Mining and Technology, Nanhu Campus, No. 1 Daxue Road, 221000, Xuzhou, China. E-mail: barkat_ullah12@outlook.com

Abdullah Rasheed Qureshi, Master of Mining Engineering, Lecturer of the Department of Mining Engineering, Balochistan University of Information Technology, Engineering and Management Sciences, Takatu Campus, Airport Road, 87300, Quetta, Pakistan. E-mail: abdullah.rasheed@,buitms.edu.pk 